\begin{tabular}{|c|l|}
\hline Title & Low-temperature selective luminescent mechanochromism of a thienyl gold isocy anide complex \\
\hline Author(s) & Seki, Tomohiro; Kobay ashi, Koh; Ito, Hajime \\
\hline Citation & $\begin{array}{l}\text { Chemical communications, 53(50), 6700-6703 } \\
\text { https://doi.org/10.1039/c7c03190d }\end{array}$ \\
\hline Issue Date & $2017-06-25$ \\
\hline Doc URL & http://hdl.handle.net/2115/70839 \\
\hline Type & article (author version) \\
\hline Additional Information & There are other files related to this item in HUSCAP. Check the above URL. \\
\hline File Information & Supplementary information.pdf \\
\hline
\end{tabular}

Instructions for use 


\section{Low-Temperature-Selective Luminescent Mechanochromism of a Thienyl Gold Isocyanide Complex}

Tomohiro Seki, ${ }^{*}$ Koh Kobayashi, and Hajime Ito*

${ }^{1}$ Division of Applied Chemistry \& Frontier Chemistry Center (FCC), Faculty of Engineering, Hokkaido University, Sapporo, Hokkaido 060-8628, Japan

seki@eng.hokudai.ac.jp

hajito@eng.hokudai.ac.jp

\section{Contents}

1. General

2. Synthesis $\quad$ S2

3. Optical properties of 1 in solution $\quad S 3$

4. DSC analysis of $1 \mathrm{R}$ upon heating $\quad$ S4

5. Optical properties of powder of $1 R$ and $1 R_{\text {Blue }} \quad S 5$

6. Recovery of the 1R from 1G upon warming $\quad S 8$

7. Optical properties and crystal structures of the single crystals of 1 S9

8. DSC analysis of 1R within the low temperature $\quad$ S15

9. Powder XRD analyses $\quad$ S16

10. Photophysical properties of $1 \quad$ S19

11. NMR spectra $\quad$ S21

12. References $\quad$ S22 


\section{General}

All commercially available reagents and solvents are of reagent grade and were used without further purification unless otherwise noted. Solvents for the synthesis were purchased from commercial suppliers, degassed by three freeze-pump-thaw cycles and further dried over molecular sieves (4 $\AA$ ). NMR spectra were recorded on a JEOL JNM-ECX400P or JNM-ECS400 spectrometer $\left({ }^{1} \mathrm{H}: 400\right.$ $\mathrm{MHz} ;{ }^{13} \mathrm{C}$ : $99.5 \mathrm{MHz}$ ) using tetramethylsilane and $\mathrm{CDCl}_{3}$ as internal standards, respectively. Excitation spectra were recorded on a Hitachi F-7000 spectrometer. Emission spectra were measured by using an Olympus fluorescence microscope BX51 equipped with Hamamatsu photonics multichannel analyzer PM-12. Absorption spectra were recorded on a Hitachi U-2910 spectrometer. The emission quantum yields of the solid samples were recorded on a Hamamatsu Quantaurus-QY Plus spectrometer with an integrating sphere. Emission lifetime measurements were recorded on a Hamamatsu Quantaurus-Tau spectrometer. DSC measurements were recorded on a SII DSC 7020 heat flux meter. Elemental analyses and low- and high resolution mass spectra were recorded at the Global Facility Center at Hokkaido University. Photographs were obtained using Olympus BX51 or SZX7 microscopes with Olympus DP72, Nikon D5100 or RICOH CX1 digital cameras. Powder diffraction data were recorded at on a Rigaku SmartLab diffractometer with $\mathrm{Cu}-\mathrm{K}_{\alpha}$ radiation and $\mathrm{D} /$ teX Ultra detector covering $5-60^{\circ}(2 \theta)$. A cooling/heating stage on JHC 10002L was used for temperature changes of solid samples.

X-ray diffraction analyses: Single crystal X-ray structural analyses were carried out on a Rigaku R-AXIS RAPID diffractometer using graphite monochromated Mo- $\mathrm{K}_{\alpha}$ radiation. The structure was solved by direct methods and expanded using Fourier techniques. Non-hydrogen atoms were refined anisotropically. Hydrogen atoms were refined using the riding model. All calculations were performed using the CrystalStructure crystallographic software package except for refinement, which was performed using SHELXL-2014. ${ }^{1}$ Simulated powder patterns were generated with Mercury $3.7^{2}$ from the structures determined by single crystal diffraction analyses. 


\section{Synthesis}

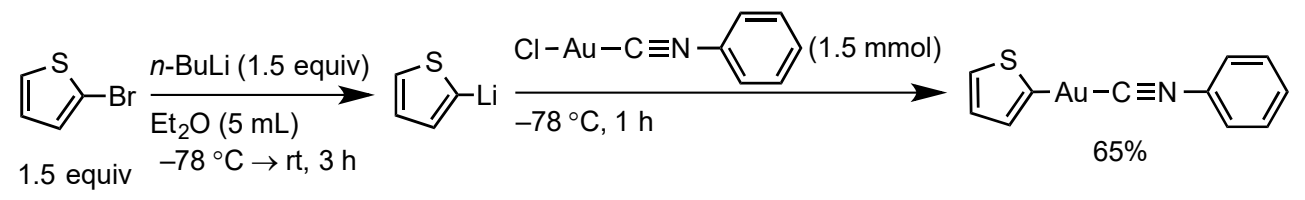

To a solution of 2-bromothiophene $(336 \mathrm{mg}, 2.25 \mathrm{mmol})$ in $5 \mathrm{ml}$ diethylether at $-78{ }^{\circ} \mathrm{C}$ under nitrogen atmosphere, a solution of $n$-BuLi in THF $(1.4 \mathrm{ml}, 2.25 \mathrm{mmol}, 1.63 \mathrm{M})$ was added dropwise with stirring. The reaction was allowed to warm to room temperature and was stirred for 1 hour to give a solution of $2.25 \mathrm{mmol}$ of 2-thienyl lithium. After cooling the resulting solution to $-78{ }^{\circ} \mathrm{C}$, a solid sample of chloro(phenyl isocyanide)gold(I) $(503 \mathrm{mg}, 1.5 \mathrm{mmol})$ was added with stirring. The reaction was allowed to warm to $0{ }^{\circ} \mathrm{C}$. After $2 \mathrm{~h}$ stirring, the reaction was quenched by the addition of a phosphate buffer solution and then extracted with $\mathrm{CH}_{2} \mathrm{Cl}_{2}$ three times and washed with $\mathrm{H}_{2} \mathrm{O}$ and brine. The organic layers were collected and dried over $\mathrm{MgSO}_{4}$. After filtration, the solvent was removed in vacuo. Further purification by short column chromatography $\left(\mathrm{SiO}_{2}, \mathrm{CH}_{2} \mathrm{Cl}_{2} /\right.$ hexane $=$ 1:1) gave a white solid of 1 (375 mg, $0.98 \mathrm{mmol}, 65 \%)$. ${ }^{1} \mathrm{H}$ NMR (400 MHz, $\left.\mathrm{CDCl}_{3}, \delta\right): 7.13$ (d, $J=$ $3.2 \mathrm{~Hz}, 1 \mathrm{H}), 7.38(\mathrm{dd}, J=3.2 \mathrm{~Hz}, 5.2 \mathrm{~Hz}, 1 \mathrm{H}), 7.50-7.61(\mathrm{~m}, 6 \mathrm{H}) .{ }^{13} \mathrm{C} \mathrm{NMR}\left(100 \mathrm{MHz}, \mathrm{CDCl}_{3}, \delta\right)$ : $124.8(\mathrm{C}), 126.7(\mathrm{CH}), 126.9(\mathrm{CH}), 127.6(\mathrm{CH}), 129.9(\mathrm{CH}), 131.3(\mathrm{CH}), 134.4(\mathrm{CH}), 158.4(C)$, 159.5 (C). MS-EI $(m / z):[\mathrm{M}+\mathrm{Na}]^{+}$calcd for $\mathrm{C}_{11} \mathrm{H}_{8} \mathrm{AuNS}$, 405.99407; found, 405.99407. Anal. Calcd for $\mathrm{C}_{11} \mathrm{H}_{8} \mathrm{AuNS}$ : C, 34.48; $\mathrm{H}, 2.10$; N, 3.66; found: $\mathrm{C}, 34.19 ; \mathrm{H}, 1.94 ; \mathrm{N}, 3.51$. 


\section{Optical properties of 1 in solution}

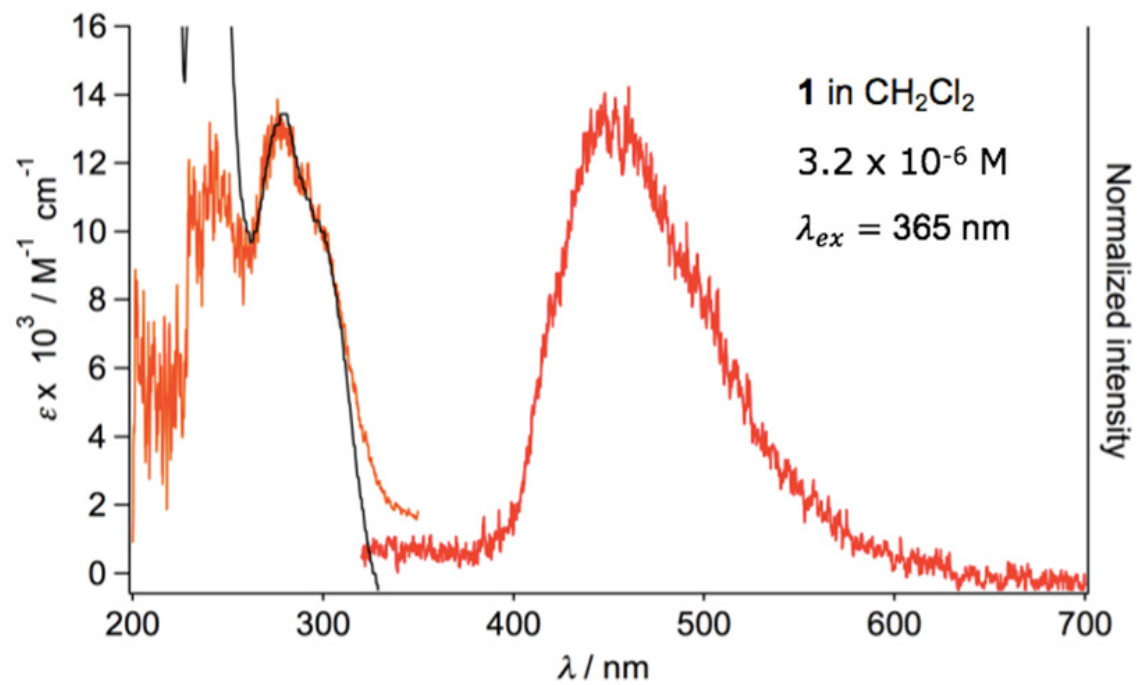

Fig. S1 UV/vis absorption (black line), excitation $\left(\lambda_{e m}=450 \mathrm{~nm}\right.$, orange line) and emission spectra $\left(\lambda_{e x}=280 \mathrm{~nm}\right.$, red line) of $\mathbf{1}$ in $\mathrm{CH}_{2} \mathrm{Cl}_{2}$ at room temperature. [1] $=3.2 \times 10^{-6} \mathrm{M}$. 


\section{DSC analysis of $1 R$ upon heating}

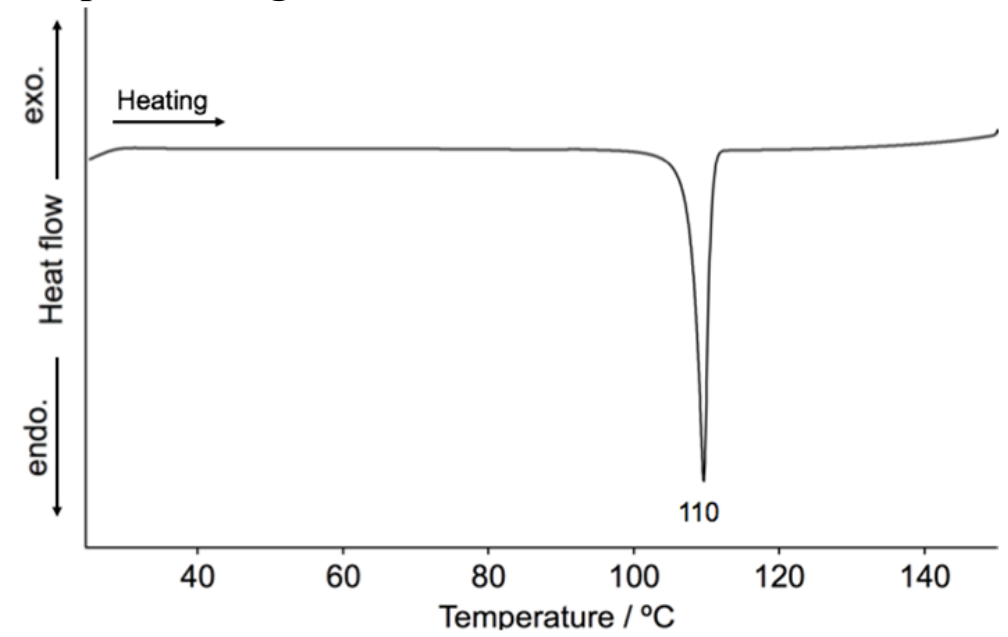

Fig. S2 DSC profile of $1 \mathbf{R}$ at a heating rate of $5{ }^{\circ} \mathrm{C} \min ^{-1}$. The peak at $110{ }^{\circ} \mathrm{C}$ is assignable to decomposition which was visually confirmed. Below decomposition temperature at $110{ }^{\circ} \mathrm{C}$, no peak was observed in DSC analyses. 
5. Optical properties of powder of $1 R$ and $1 R_{\text {Blue }}$

a)
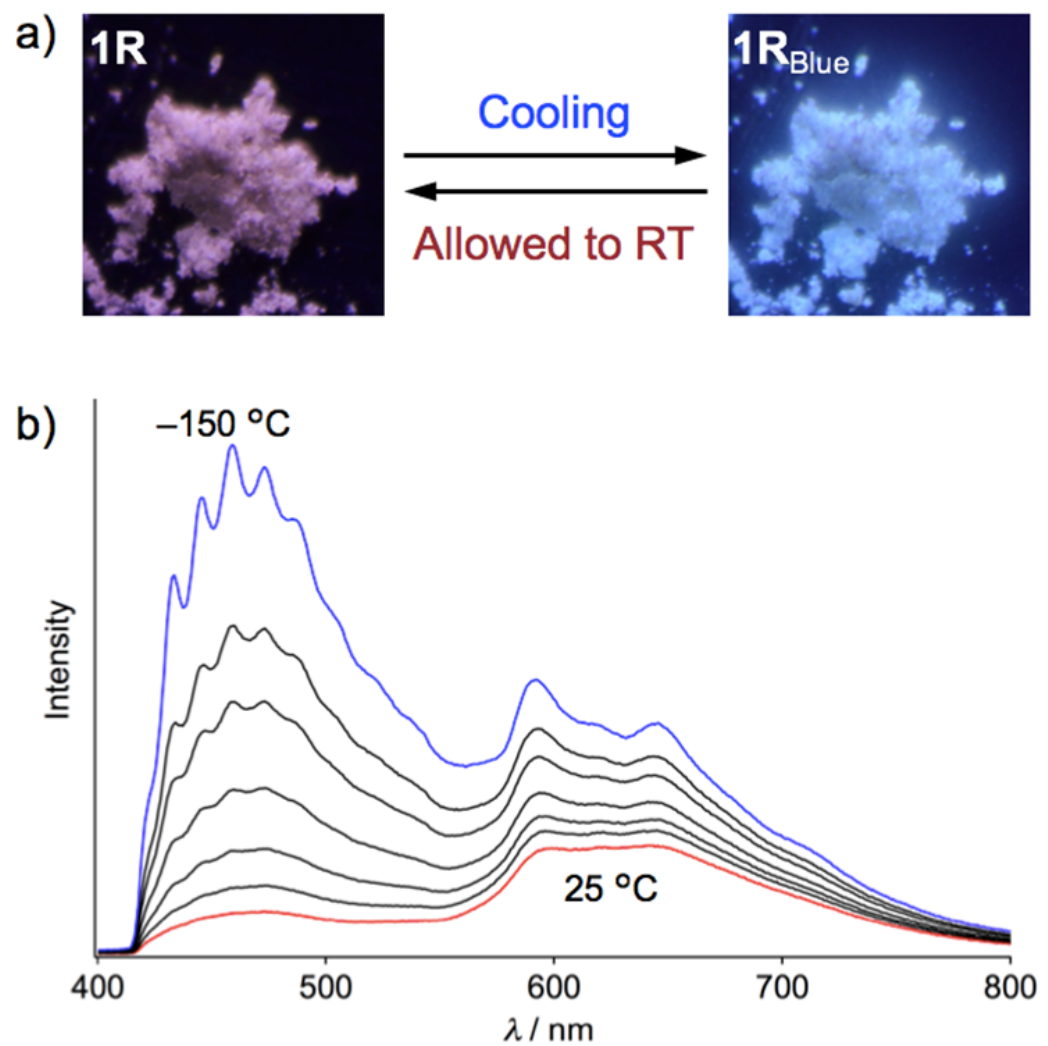

Fig. S3 a) Photographs of $1 \mathbf{R}$ taken at $25^{\circ} \mathrm{C}$ and $\mathbf{1} \mathbf{R}_{\text {Blue }}$ taken at $-75^{\circ} \mathrm{C}$ with the excitation at $365 \mathrm{~nm}$. b) Emission spectral changes upon cooling $1 \mathbf{R}$ from $25^{\circ} \mathrm{C}$ (red line) to $-150{ }^{\circ} \mathrm{C}$ (blue line) with the excitation at $365 \mathrm{~nm}$. Measurement temperature: $25,0,-25,-50,-75,-100,-150{ }^{\circ} \mathrm{C}$. 
a)

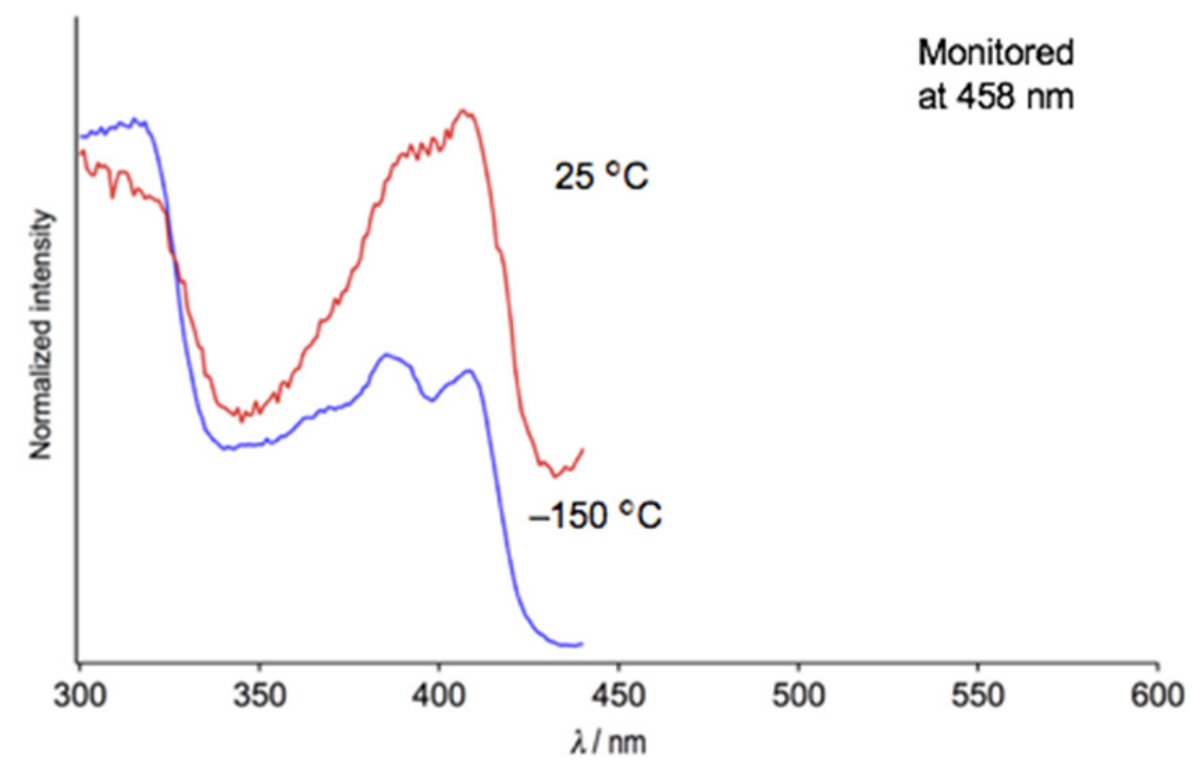

b)

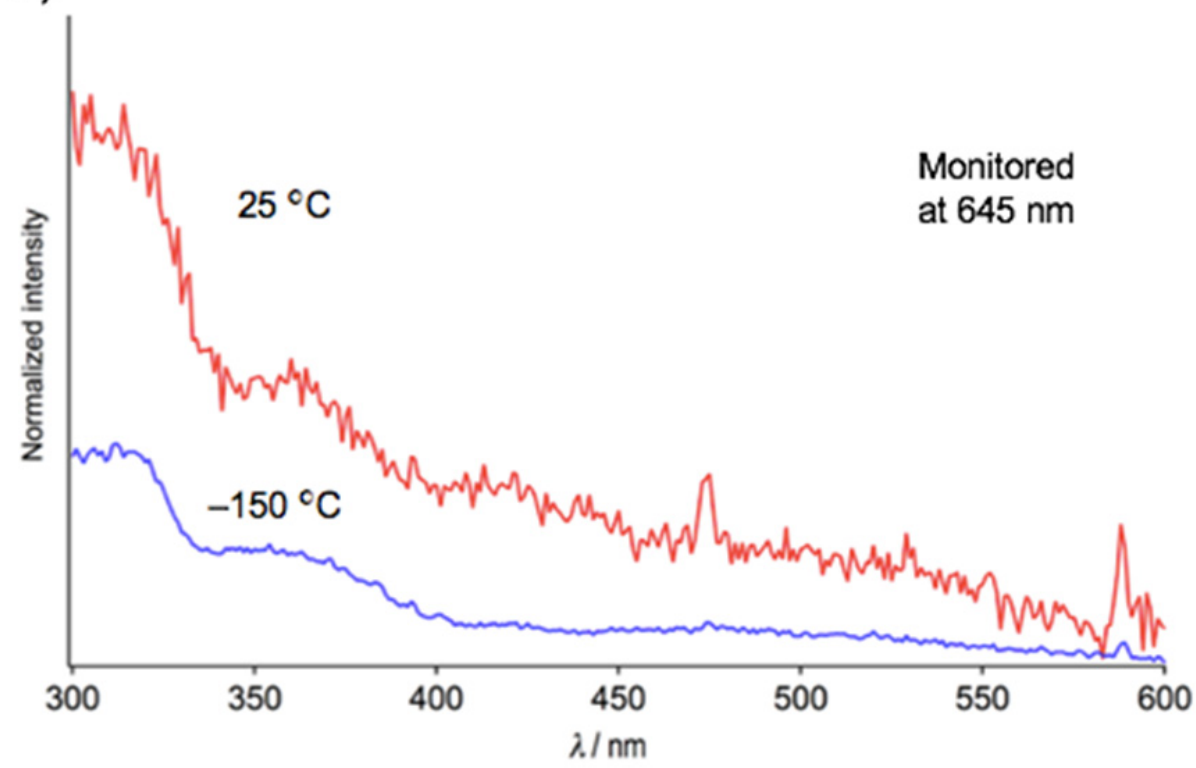

Fig. S4 Excitation spectra of $\mathbf{1 R}\left(25^{\circ} \mathrm{C}\right.$, red lines $)$ and $\mathbf{1} \mathbf{R}_{\text {Blue }}\left(-150{ }^{\circ} \mathrm{C}\right.$, blue lines $)$ monitored at a) $458 \mathrm{~nm}$ and b) $645 \mathrm{~nm}$. 
a)

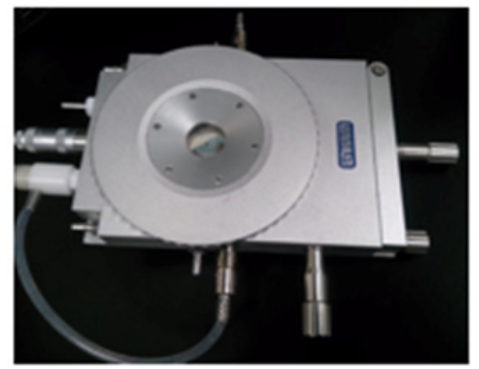

b)

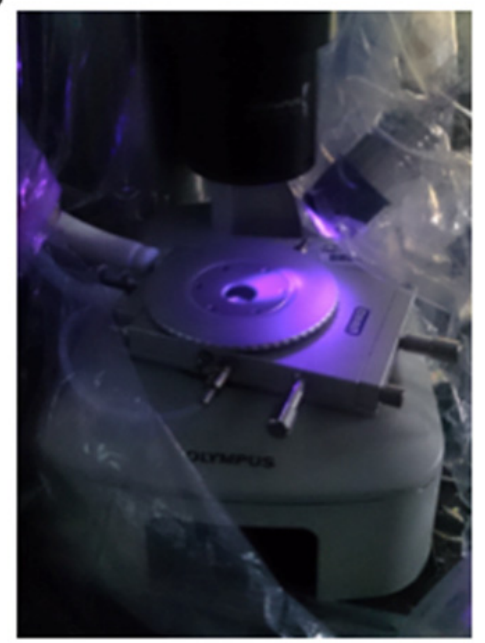

c)

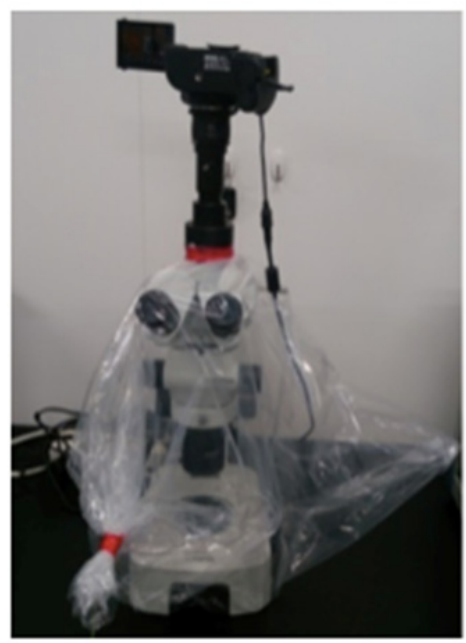

Fig. S5 a) Photographs of a heating/cooling stage and b) Photographs of the heating/cooling stage within plastic bag filled with nitrogen gas. c) Photographs of a microscope in nitrogen-filled plastic bag.

Note: To prevent the formation of ice on $\mathbf{1}$, we prepared for a plastic bag filled with nitrogen gas into which 1R, a heating/cooling stage, and a spatula were placed, then mechanical stimulation is applied to afford 1G. Under air, mechanochromism of $\mathbf{1}$ at low temperature is also observed. 


\section{Recovery of the $1 \mathrm{R}$ from $1 \mathrm{G}$ upon warming}

a)

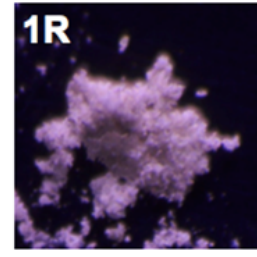

$25^{\circ} \mathrm{C}$ i) Cooled to $-75^{\circ} \mathrm{C}$ ii) Grinding

b)

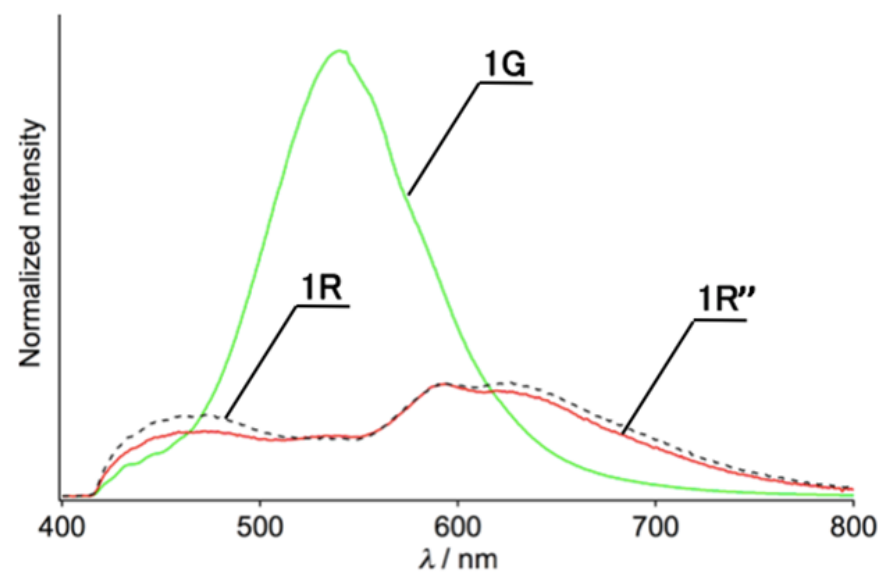

Fig. S6 a) Photographs of solid samples of $1 \mathbf{R}\left(25^{\circ} \mathrm{C}\right.$, left $)$ and $\mathbf{1 G}\left(-75^{\circ} \mathrm{C}\right.$, middle) and a solid

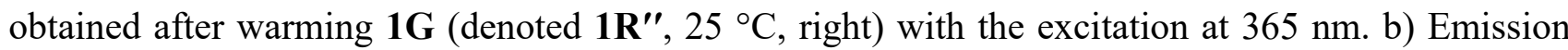
spectra of solid samples of $\mathbf{1 R}\left(25^{\circ} \mathrm{C}\right.$, black dotted line $)$ and $\mathbf{1 G}\left(-75^{\circ} \mathrm{C}\right.$, green line $)$ and a solid obtained after warming $\mathbf{1 G}\left(\mathbf{1 R}^{\prime \prime}, 25^{\circ} \mathrm{C}\right.$, red solid line $)$. 


\section{Optical properties and crystal structures of the single crystals of 1}

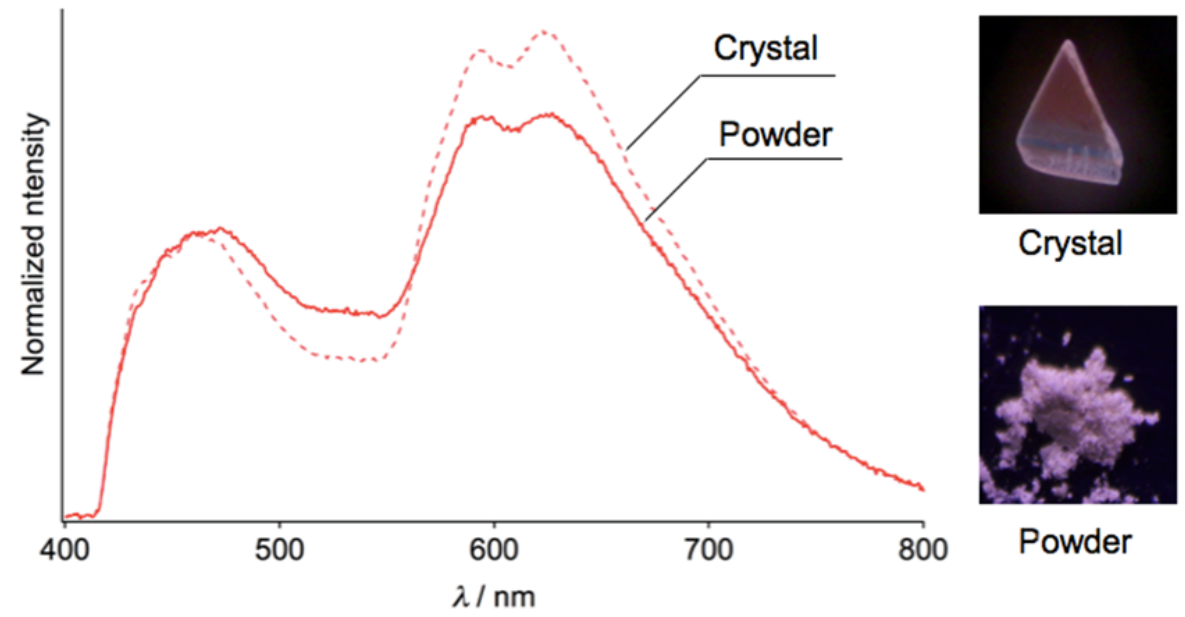

Fig. S7 Emission spectra of a powder sample of $\mathbf{1 R}$ (solid line) and red-emitting single crystal obtained by recrystallization (dotted line) with the excitation at $365 \mathrm{~nm}$. Inset shows photographs of a red-emitting single crystal obtained by recrystallization (upper) and a powder sample of 1R (lower) taken under UV illumination. 
a)
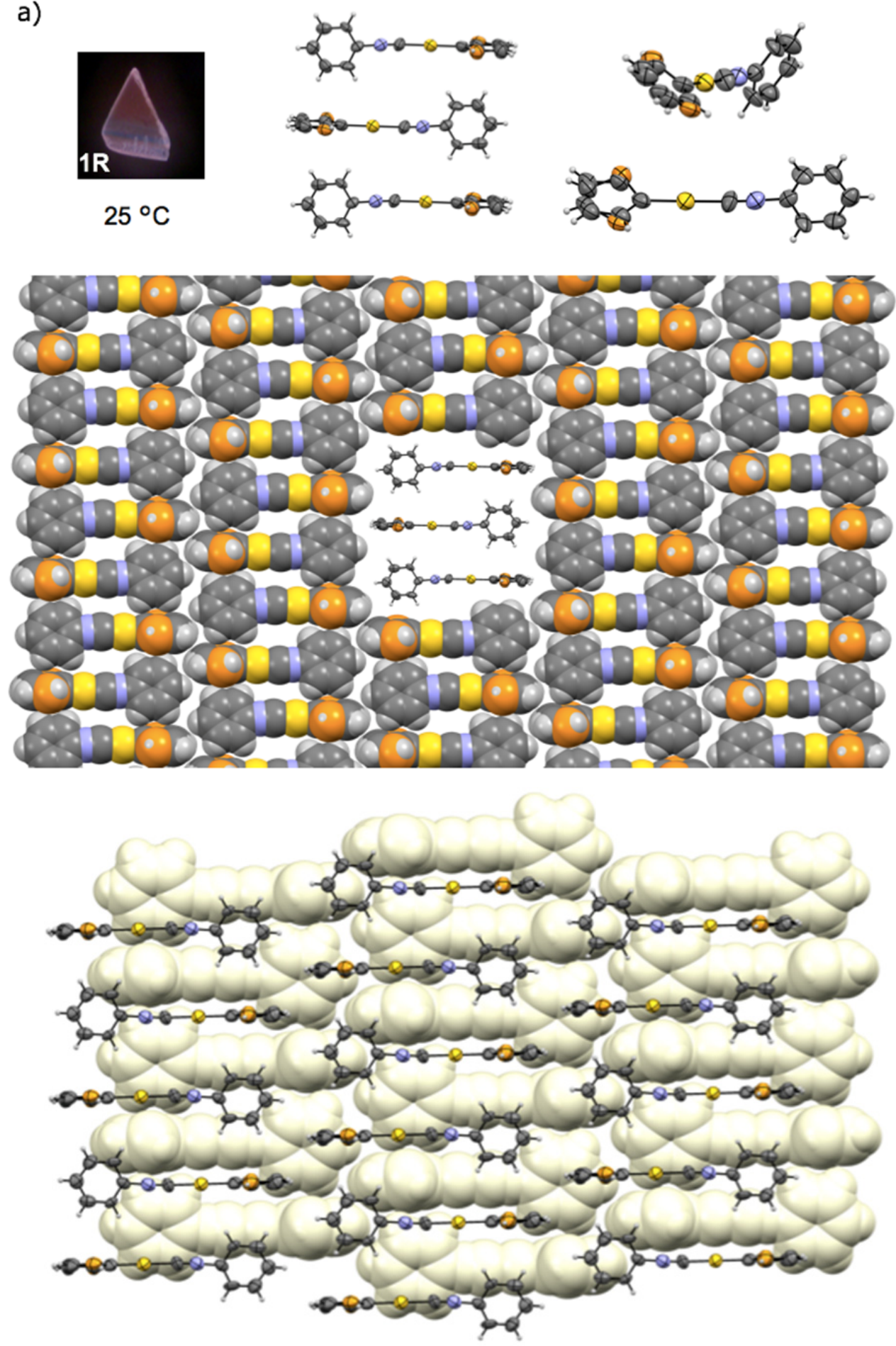
b)
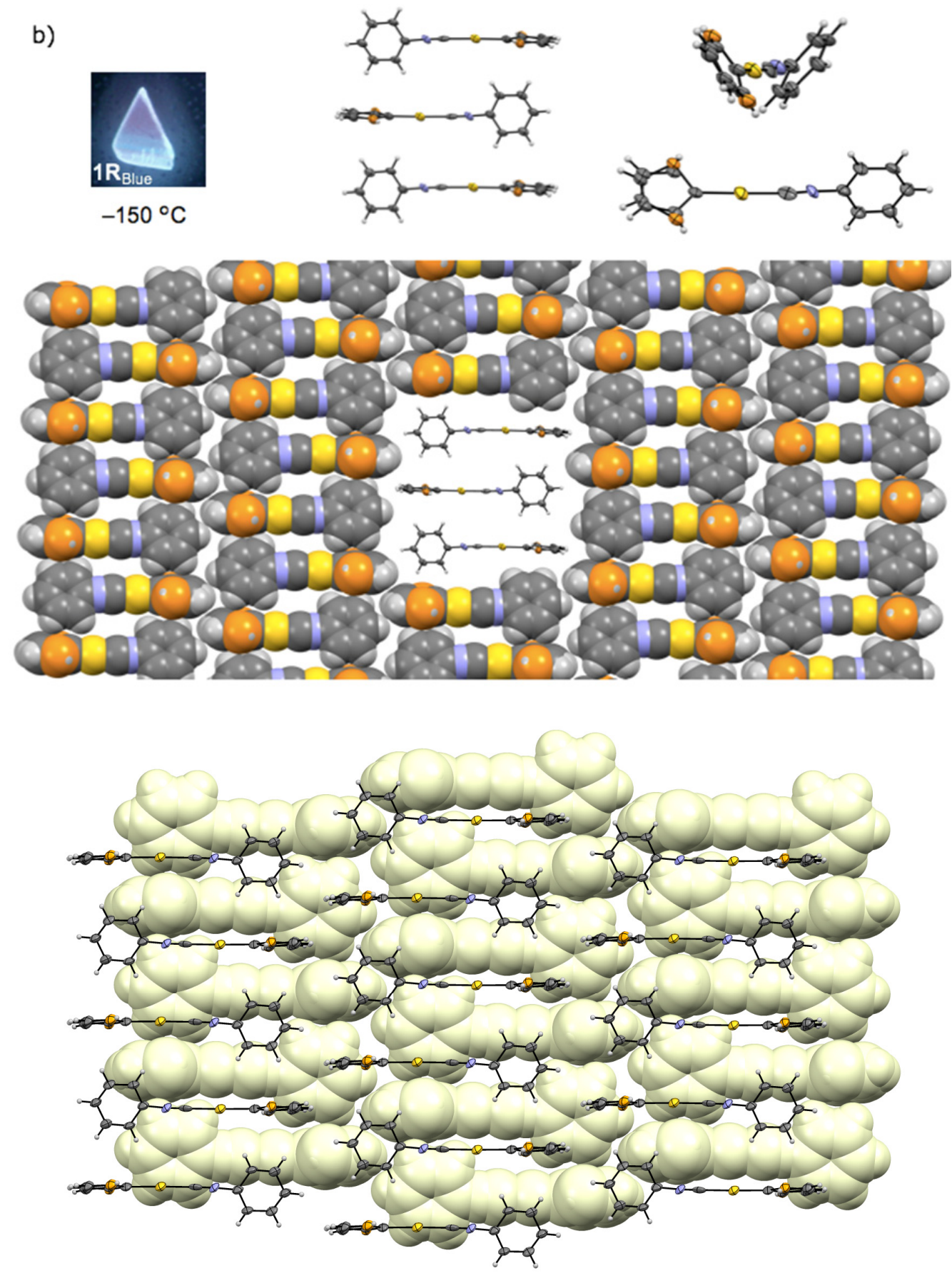

Fig. S8 Photographs and single-crystal structures of a) red-emitting crystal of $\mathbf{1}$ (measured at $25{ }^{\circ} \mathrm{C}$ ) and b) blue-emitting crystal of $\mathbf{1}$ (measured at $-150^{\circ}$ ), which are corresponding to $\mathbf{1} \mathbf{R}$ and $\mathbf{1} \mathbf{R}_{\text {Blue, }}$ respectively. 
Table S1. Summary of X-ray crystallographic data for 1 at $-150{ }^{\circ} \mathrm{C}$ and $25^{\circ} \mathrm{C}$.

\begin{tabular}{|c|c|c|}
\hline Polymorph & $1 R$ & $\mathbf{1} \mathbf{R}_{\text {Blue }}$ \\
\hline CCDC Name & 1537737 & 1537738 \\
\hline Empirical Formula & $\mathrm{C}_{11} \mathrm{H}_{8} \mathrm{AuNS}$ & $\mathrm{C}_{11} \mathrm{H}_{8} \mathrm{AuNS}$ \\
\hline Formula Weight & 383.22 & 383.22 \\
\hline Crystal System & triclinic & triclinic \\
\hline Crystal Size / mm & $0.114 \times 0.068 \times 0.015$ & $0.114 \times 0.068 \times 0.015$ \\
\hline$a / \AA$ & $5.850(3)$ & $5.7510(11)$ \\
\hline$b / \AA$ & $8.472(4)$ & $8.2449(13)$ \\
\hline$c / \AA$ & $11.703(6)$ & $11.8285(19)$ \\
\hline$\alpha /{ }^{\circ}$ & $102.488(10)$ & $103.379(4)$ \\
\hline$\beta /{ }^{\circ}$ & $99.645(9)$ & $99.477(5)$ \\
\hline$\gamma / \circ$ & $96.731(9)$ & $95.776(5)$ \\
\hline$V / \AA^{3}$ & $551.1(5)$ & $532.54(15)$ \\
\hline Space Group & $P-1(\# 2)$ & $P-1(\# 2)$ \\
\hline$Z$ value & 2 & 2 \\
\hline$D_{\text {calc } / \mathrm{g} \cdot \mathrm{cm}^{-3}}$ & 2.309 & 2.390 \\
\hline Temperature / K & 298 & 123 \\
\hline $2 \theta_{\max } /^{\circ}$ & 55.0 & 55.0 \\
\hline$\mu\left(\mathrm{MoK}_{\alpha}\right) / \mathrm{cm}^{-1}$ & 135.397 & 140.128 \\
\hline No. of Reflections & Total: 5278 & Total: 5261 \\
\hline Measured & $\begin{array}{l}\text { Unique : } 2496 \\
\left(R_{\text {int }}=0.1115\right)\end{array}$ & $\begin{array}{l}\text { Unique }: 2423 \\
\left(R_{\text {int }}=0.0943\right)\end{array}$ \\
\hline $\begin{array}{l}\text { Residuals: } R_{1} \\
(\mathrm{I}>2.00 \sigma(\mathrm{I})) / \%\end{array}$ & 7.25 & 7.76 \\
\hline $\begin{array}{l}\text { Residuals: } w R_{2} \\
\text { (All reflections) / \% }\end{array}$ & 17.52 & 13.94 \\
\hline Goodness of Fit (GOF) & 0.978 & 1.136 \\
\hline $\begin{array}{l}\text { Maximum peak in } \\
\text { Final Diff. Map / } \AA^{3}\end{array}$ & $0.77 \mathrm{e}^{-}$ & $2.53 \mathrm{e}^{-}$ \\
\hline $\begin{array}{l}\text { Minimum peak in } \\
\text { Final Diff. Map / } \AA^{3}\end{array}$ & $-1.15 . \mathrm{e}^{-}$ & $-5.17 \mathrm{e}^{-}$ \\
\hline
\end{tabular}


a)

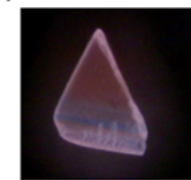

$25^{\circ} \mathrm{C}$

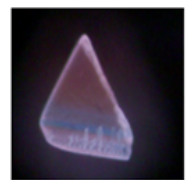

$0^{\circ} \mathrm{C}$

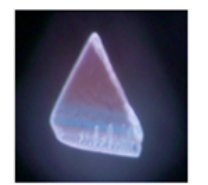

$-25^{\circ} \mathrm{C}$

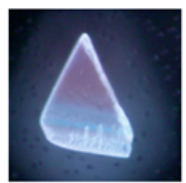

$-50^{\circ} \mathrm{C}$

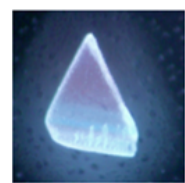

$-75^{\circ} \mathrm{C}$

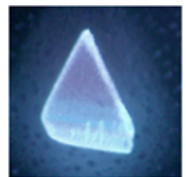

$-100^{\circ} \mathrm{C}$

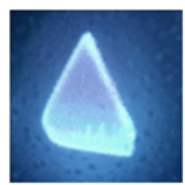

$-150^{\circ} \mathrm{C}$

b)

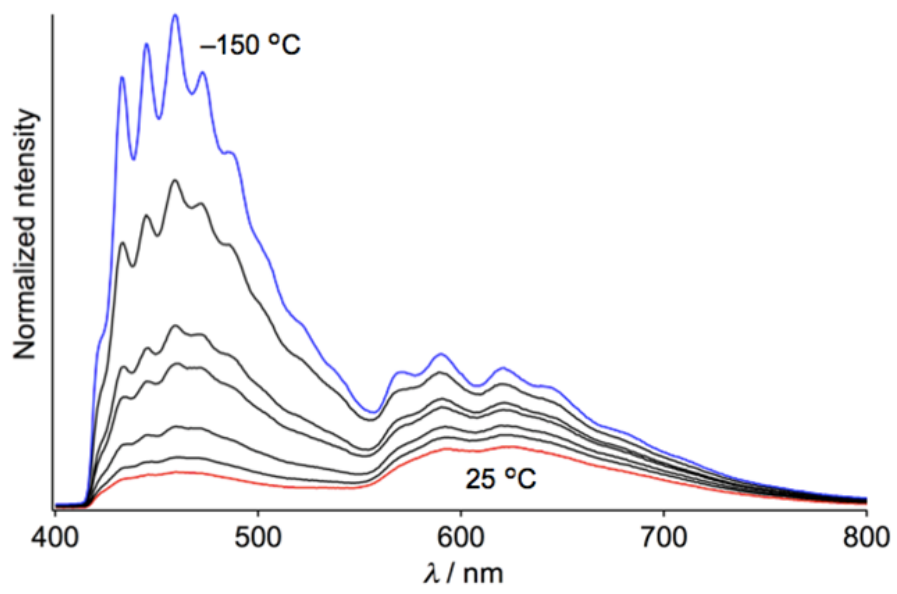

Fig. S9 a) Photographs of a crystal of 1 under UV light at various temperature. b) Emission spectral changes of single crystals of 1 at range from $25^{\circ} \mathrm{C}$ to $-150{ }^{\circ} \mathrm{C}$.

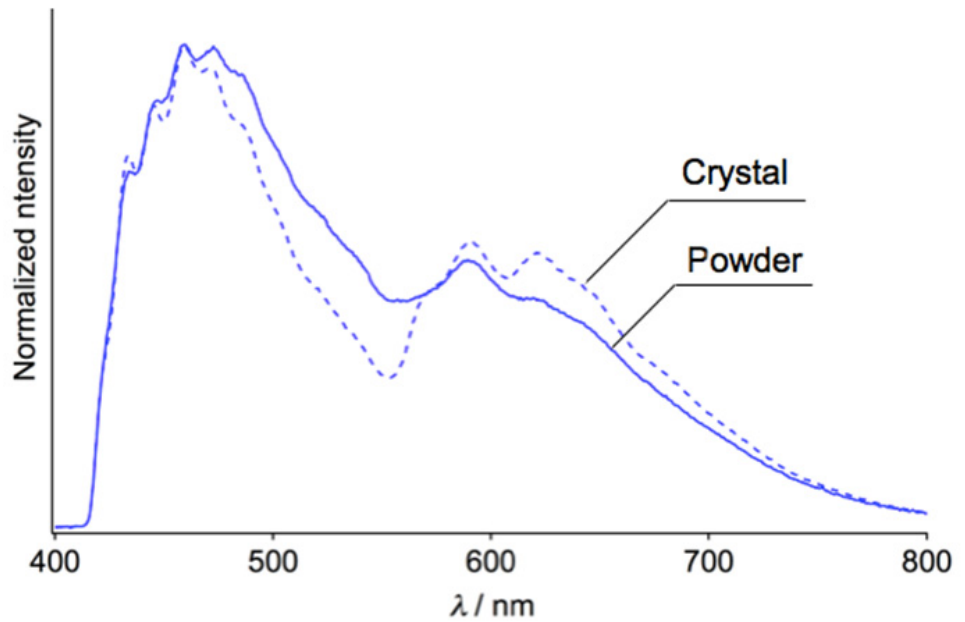

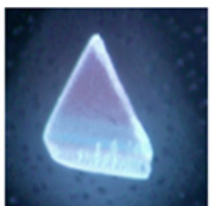

Crystal

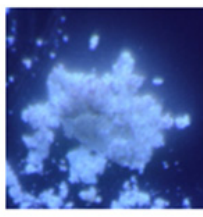

Powder

Fig. S10 Emission spectra of a powder sample of $\mathbf{1} \mathbf{R}_{\text {Blue }}\left(-75^{\circ} \mathrm{C}\right.$, solid line $)$ and blue-emitting single crystal $\left(-75{ }^{\circ} \mathrm{C}\right.$, dotted line) with the excitation at $365 \mathrm{~nm}$. Inset shows photographs of a blue-emitting single crystal obtained by recrystallization $\left(-75^{\circ} \mathrm{C}\right.$, upper $)$ and a powder sample of $\mathbf{1} \mathbf{R}_{\text {Blue }}\left(-75^{\circ} \mathrm{C}\right.$, lower) taken under UV illumination. 


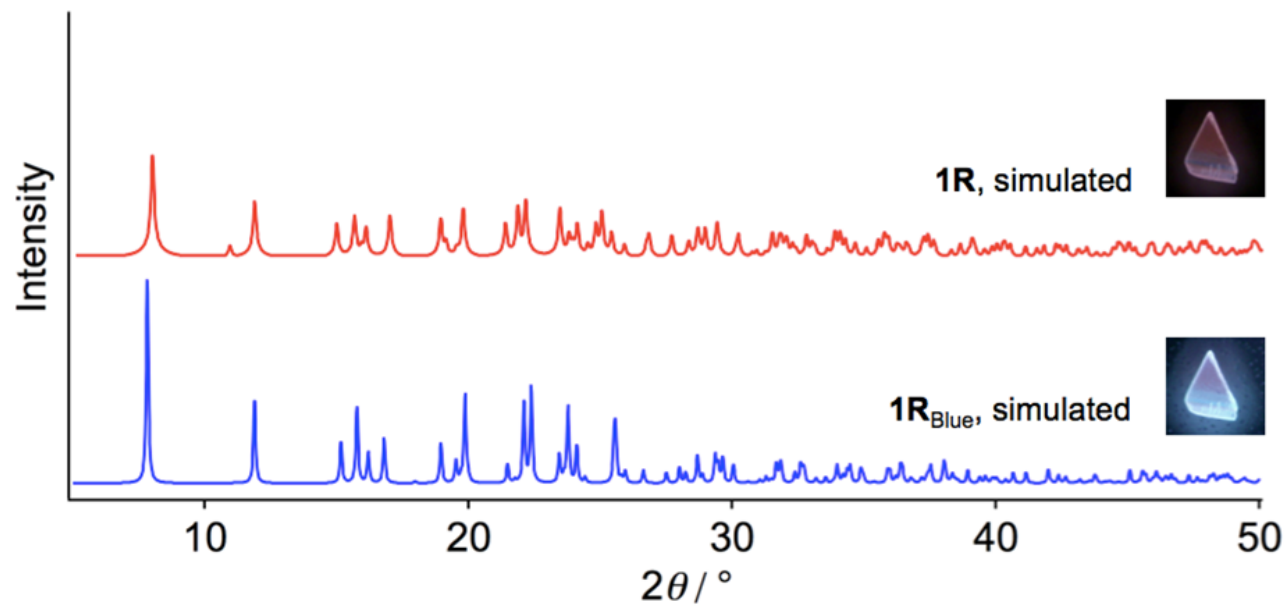

Fig. S11 Simulated powder XRD patterns derived from the red- and blue-emitting single crystals, corresponding to $\mathbf{1} \mathbf{R}$ and $\mathbf{1} \mathbf{R}_{\mathrm{Blue}}$, respectively. 


\section{DSC analysis of $1 \mathrm{R}$ within the low temperature}

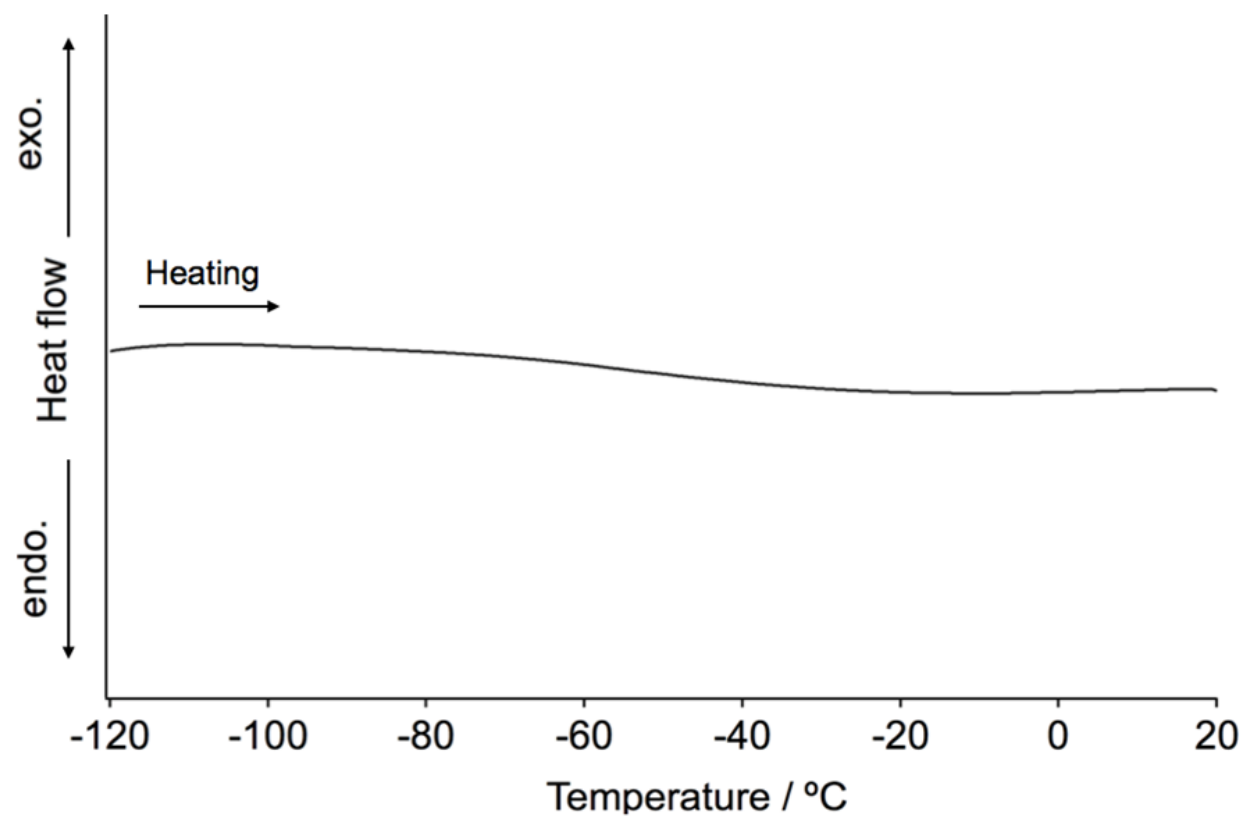

Fig. S12 DSC analysis of 1 ranging from $-120{ }^{\circ} \mathrm{C}$ to $20{ }^{\circ} \mathrm{C}$ at a heating rate of $5{ }^{\circ} \mathrm{C} \mathrm{min}-1$. Because of limitation of our instrument, we can not perform DSC analyses of samples during cooling. Thus, this measurement is performed upon heating of $\mathbf{1} \mathbf{R}_{\text {Blue }}$ from $-120{ }^{\circ} \mathrm{C}$. 


\section{Powder XRD analyses}

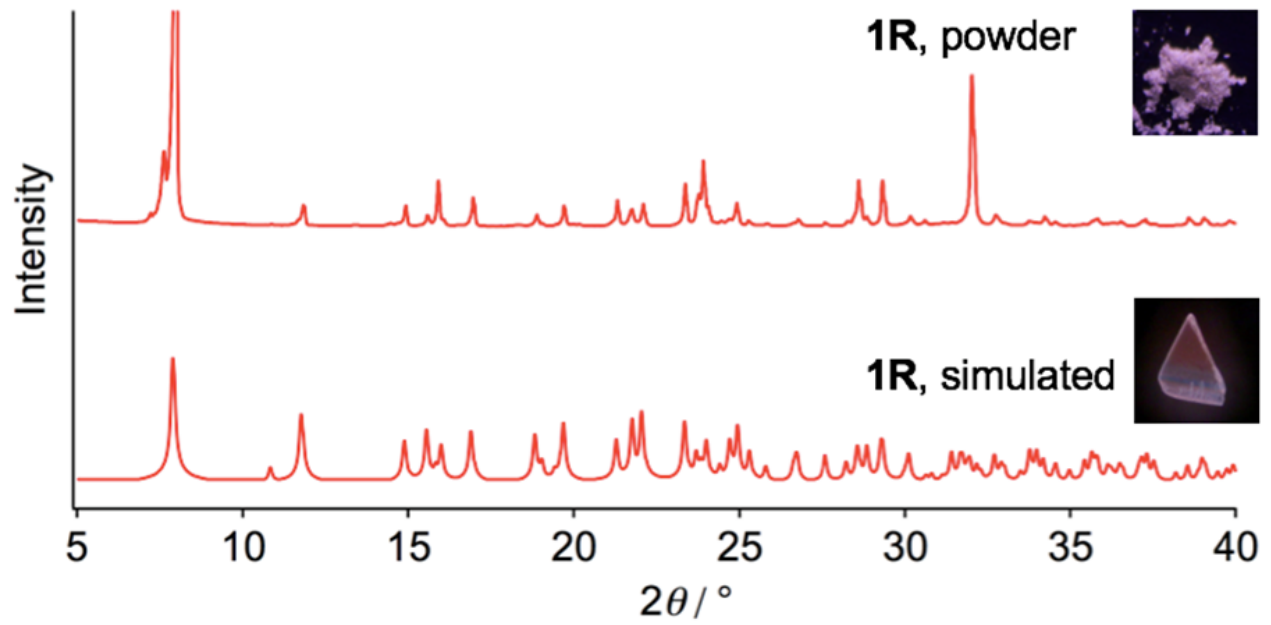

Fig. S13 Powder XRD pattern of $1 R$ at room temperature (upper pattern) and simulated powder XRD pattern of the red-emitting single crystal of $\mathbf{1}$ (lower pattern). 

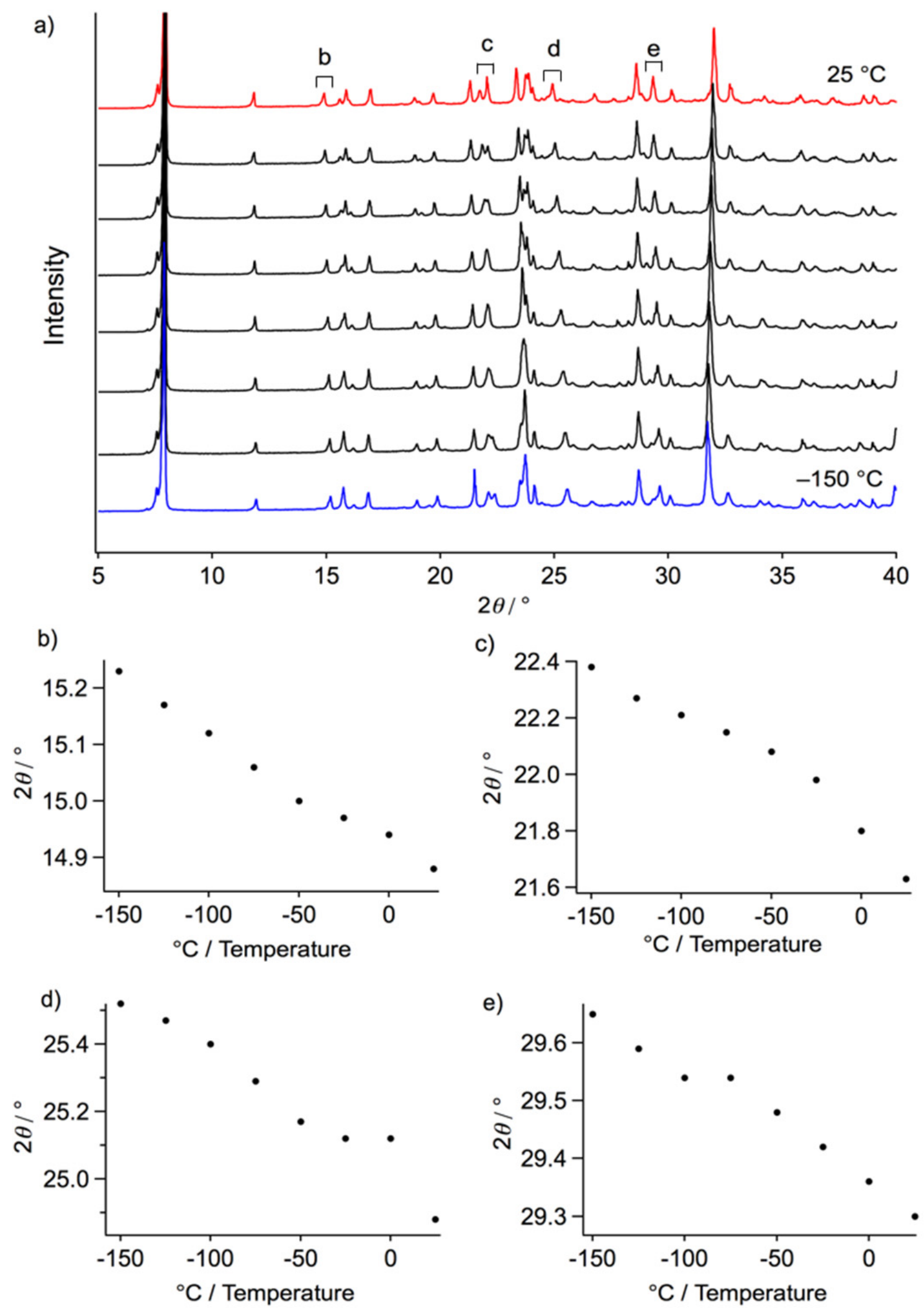

Fig. S14 a) Temperature-dependent powder XRD patterns of 1. Measurement temperature: 25, 0, -25, $-50,-75,-100,-150{ }^{\circ} \mathrm{C}$. b-e) Plots of a position of specific peaks with respect to temperature, indicating gradual peak shifts. 


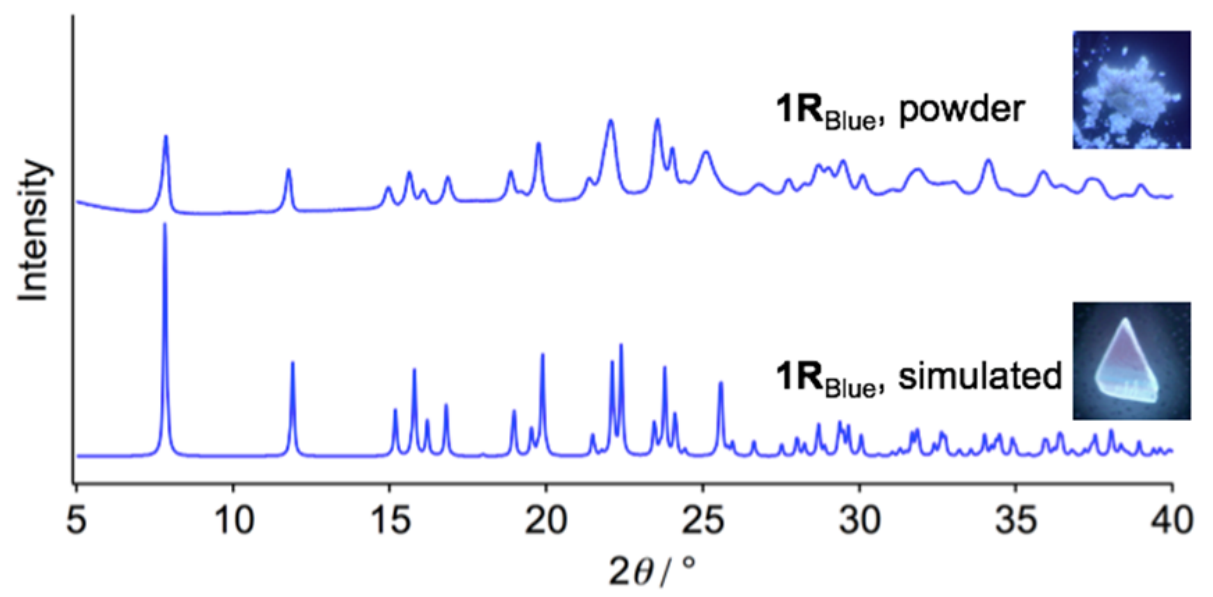

Fig. S15 Powder XRD pattern of $\mathbf{1} \mathbf{R}_{\text {Blue }}$ at $-150{ }^{\circ} \mathrm{C}$ (upper pattern) and simulated powder XRD pattern of the blue-emitting single crystal of $\mathbf{1}$ (lower pattern).
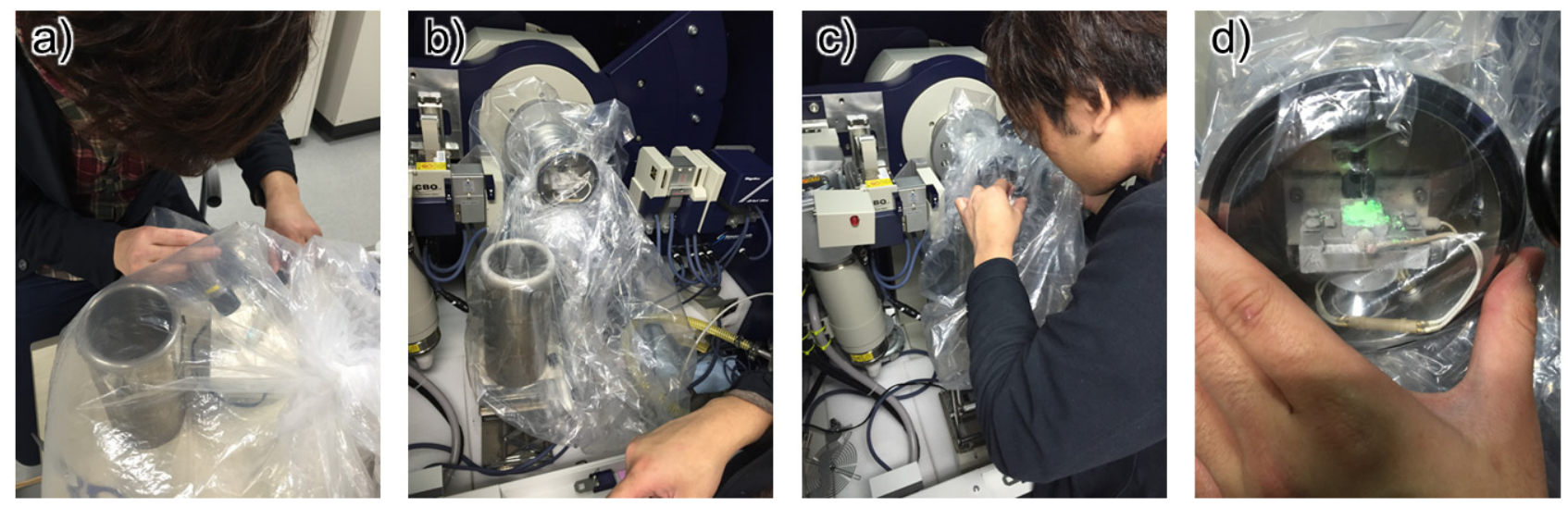

Fig. S16 Photographs when 1G samples for powder XRD analyses were prepared.

Note: For the powder XRD measurements of $\mathbf{1 G}$, the ground powder sample was prepared under a nitrogen atmosphere as follows: into a plastic bag filled with nitrogen gas, a test tube was inserted that contained $1 \mathbf{R}$ and a stirring bar (Fig. S16a). This test tube was inserted in a liquid nitrogen bath (1R $\left.\rightarrow \mathbf{1} \mathbf{R}_{\text {Blue }}\right)$, before stirring was applied for $3 \mathrm{~h}\left(\mathbf{1 R}_{\text {Blue }} \rightarrow \mathbf{1 G}\right)$. The sample stage of the powder XRD apparatus was also covered with a nitrogen-filled plastic bag and cooled to $-150{ }^{\circ} \mathrm{C}$ (Fig. S16b). Then, the $\mathbf{1 G}$ sample in the test tube was transferred to the cooled sample stage in order to carry out the powder XRD measurements (Fig. S16c). After confirming the green photoluminescence of the sample (Fig. S16d), the sample stage chamber was sealed and evacuated, before the powder XRD measurement was carried out. 


\section{Photophysical properties of 1}

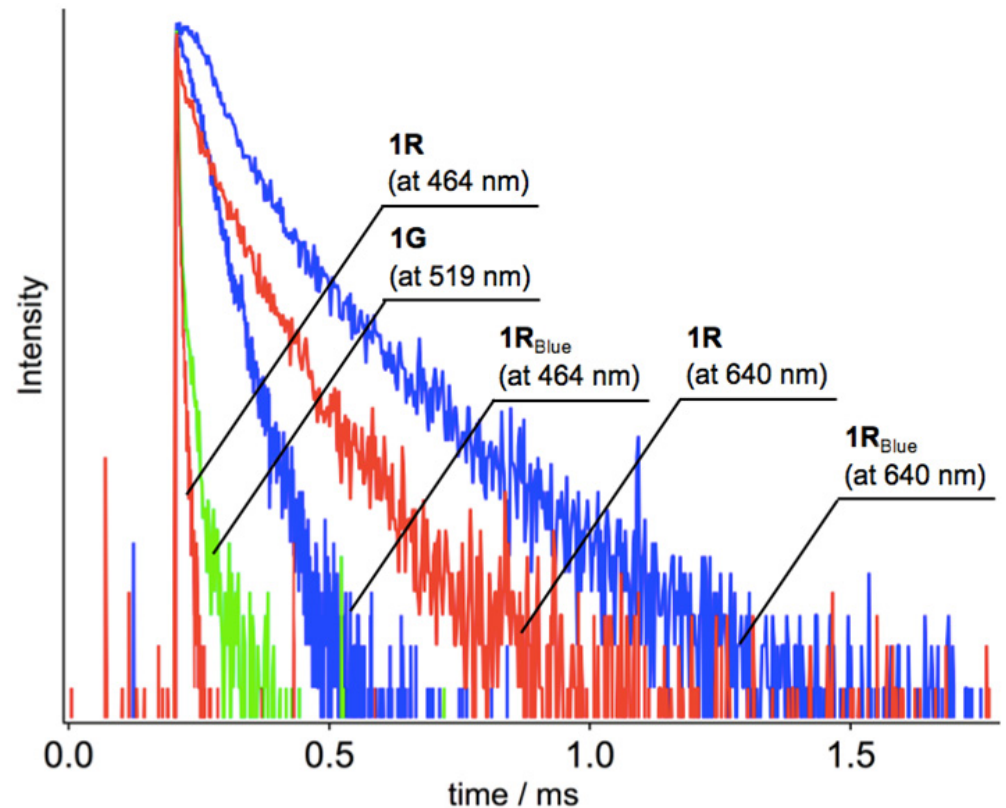

Fig. S17 Emission decay profiles of $\mathbf{1 R}, \mathbf{1} \mathbf{R}_{\text {Blue, }}$ and $\mathbf{1 G}$ with the excitation at $370 \mathrm{~nm}$. Monitored emission wavelengths are $464 \mathrm{~nm}$ for $\mathbf{1 R}$ and $\mathbf{1} \mathbf{R}_{\text {Blue, }} 519 \mathrm{~nm}$ for $\mathbf{1 G}$, and $640 \mathrm{~nm}$ for $\mathbf{1 R}$ and $\mathbf{1} \mathbf{R}_{\text {Blue. }}$

Table S2. Summary of photophysical data of $\mathbf{1 .}$

\begin{tabular}{|c|c|c|c|c|c|}
\hline & $\chi^{\prime}-$ & $\tau_{\mathrm{av}}^{\mathrm{b}, \mathrm{c}} / \mu \mathrm{s}$ & $\begin{array}{l}\tau_{1} / \mu \mathrm{s} \\
(A /-)\end{array}$ & $\begin{array}{l}\tau_{2} / \mu \mathrm{s} \\
(A /-)\end{array}$ & $\begin{array}{l}\tau_{3} / \mu \mathrm{s} \\
(A /-)\end{array}$ \\
\hline $\begin{array}{l}1 \mathbf{R} \\
(\text { at } 640 \mathrm{~nm})^{\mathrm{a}}\end{array}$ & 1.11 & 83 & $\begin{array}{l}1.4 \\
(0.75)\end{array}$ & $\begin{array}{l}27.2 \\
(0.10)\end{array}$ & $\begin{array}{l}99.1 \\
(0.15)\end{array}$ \\
\hline $\begin{array}{l}\mathbf{1 R} \\
(\text { at } 464 \mathrm{~nm})^{\mathrm{a}}\end{array}$ & 1.38 & 1 & $\begin{array}{l}0.50 \\
(0.61)\end{array}$ & $\begin{array}{l}1.73 \\
(0.39)\end{array}$ & - \\
\hline $\begin{array}{l}\mathbf{1 R}_{\text {Blue }} \\
(\text { at } 640 \mathrm{~nm})^{\mathrm{a}}\end{array}$ & 1.30 & 127 & $\begin{array}{l}0.52 \\
(0.62)\end{array}$ & $\begin{array}{l}65.3 \\
(0.30)\end{array}$ & $\begin{array}{l}203.5 \\
(0.08)\end{array}$ \\
\hline $\begin{array}{l}\mathbf{1 R}_{\text {Blue }} \\
(\text { at } 464 \mathrm{~nm})^{\mathrm{a}}\end{array}$ & 1.26 & 41 & $\begin{array}{l}0.43 \\
(0.77)\end{array}$ & $\begin{array}{l}31.0 \\
(0.16)\end{array}$ & $\begin{array}{l}54.9 \\
(0.08)\end{array}$ \\
\hline $\begin{array}{l}\mathbf{1 G} \\
(\text { at } 519 \mathrm{~nm})^{\mathrm{a}}\end{array}$ & $-{ }^{d}$ & $-{ }^{d}$ & $-{ }^{d}$ & $-{ }^{\mathrm{d}}$ & $-{ }^{d}$ \\
\hline
\end{tabular}

a: Monitored emission wavelength is shown in parentheses. ${ }^{\mathrm{b}}: \tau_{\mathrm{av}}$ is defined as: $\Sigma\left(A_{\mathrm{n}} \tau_{\mathrm{n}}{ }^{2}\right) / \Sigma\left(A_{\mathrm{n}} \tau_{\mathrm{n}}\right){ }^{\mathrm{c}}: \lambda_{\mathrm{ex}}=370 \mathrm{~nm} .{ }^{\mathrm{d}}$ : Fitting failed. 

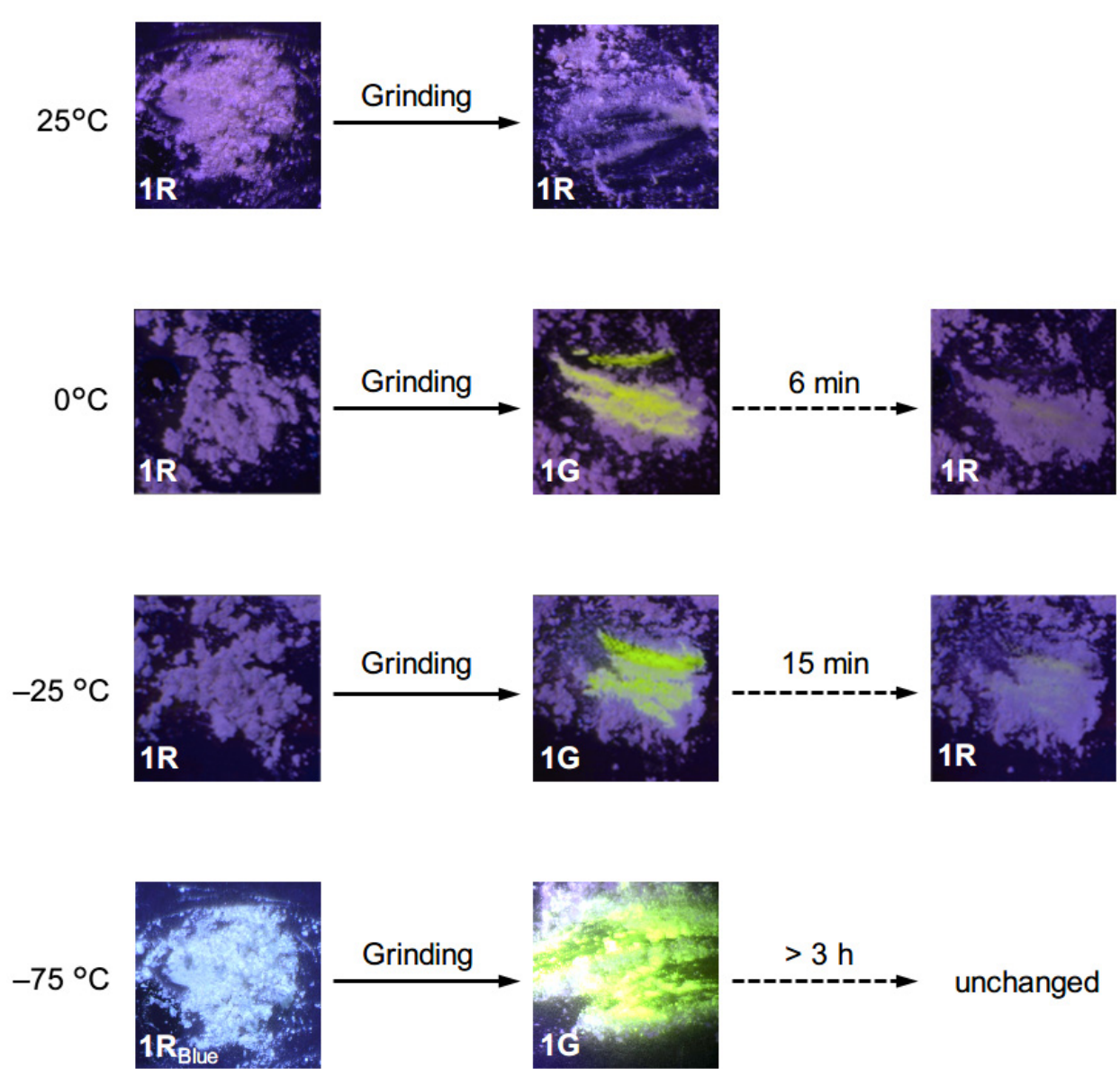

Fig. S18 Photographs of solid samples of 1 taken under UV light when mechanically stimulated at various temperature. It should be note that we also confirmed that $\mathbf{1 G}$ is intact for more than one day at $-78^{\circ} \mathrm{C}$, when $1 \mathrm{G}$ was obtained by mechanical stimulation with a stirring bar in a test tube, where the sample can be kept easily at $-78{ }^{\circ} \mathrm{C}$ for longer periods by using a dry ice/hexane bath.

This experiment was carried out as follows: the heating/cooling stage containing $1 \mathbf{R}$ on a glass plate was sealed with a lid, not with plastic bag (see Figure A below), in order to prevent the sample from being exposed to too much air. The sample was cooled to $0,-25$, or $-75^{\circ} \mathrm{C}$, before the seal was opened to scratch the sample ten times with a spatula (Figure B). Subsequently, an emission-color change of the sample to green was observed at the scratched areas (Fig. S18). After ten scratches, the lid was closed again (Figure C) and we examined the time necessary for the reverse emission-color changes.
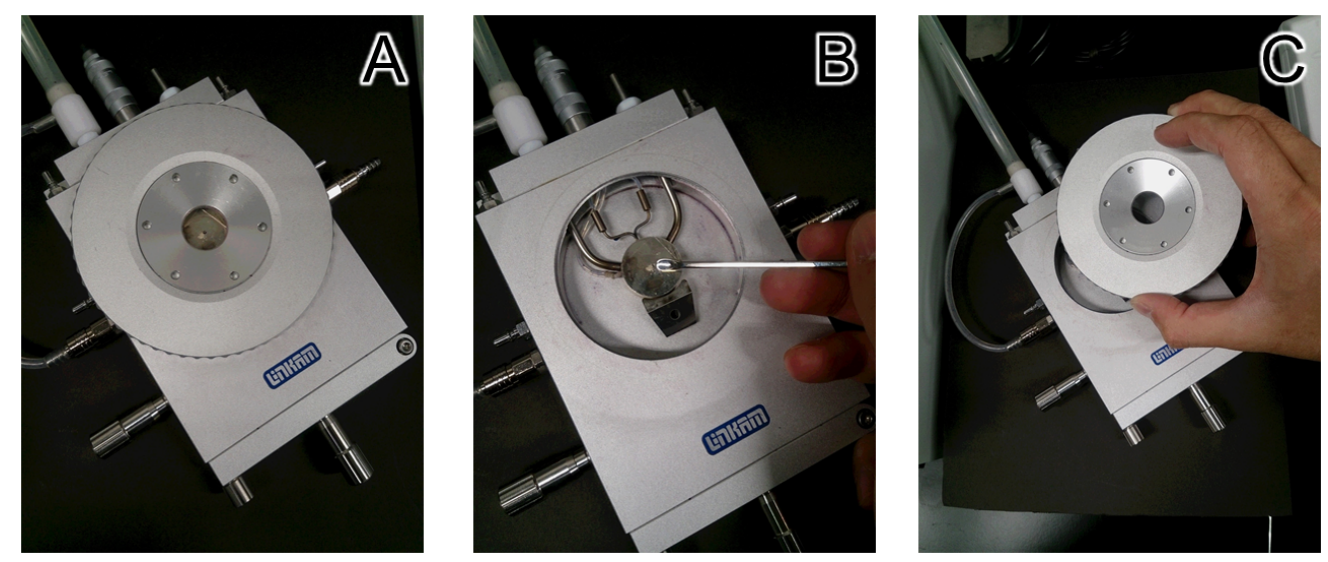


\section{NMR spectra}

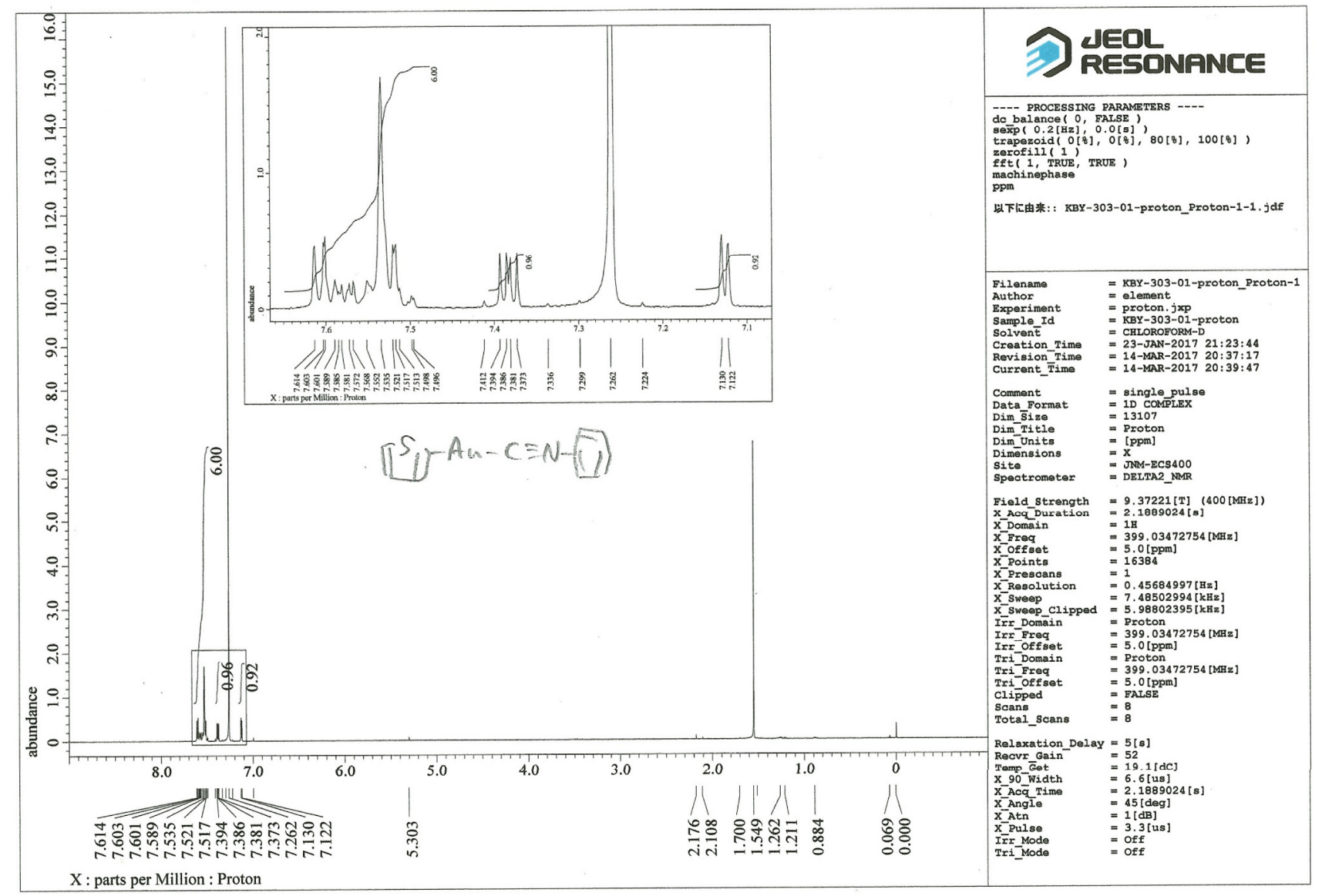

Fig. $\mathbf{S 1 9}{ }^{1} \mathrm{H}$ NMR spectrum of $\mathbf{1}$ dissolved in $\mathrm{CDCl}_{3}$. 


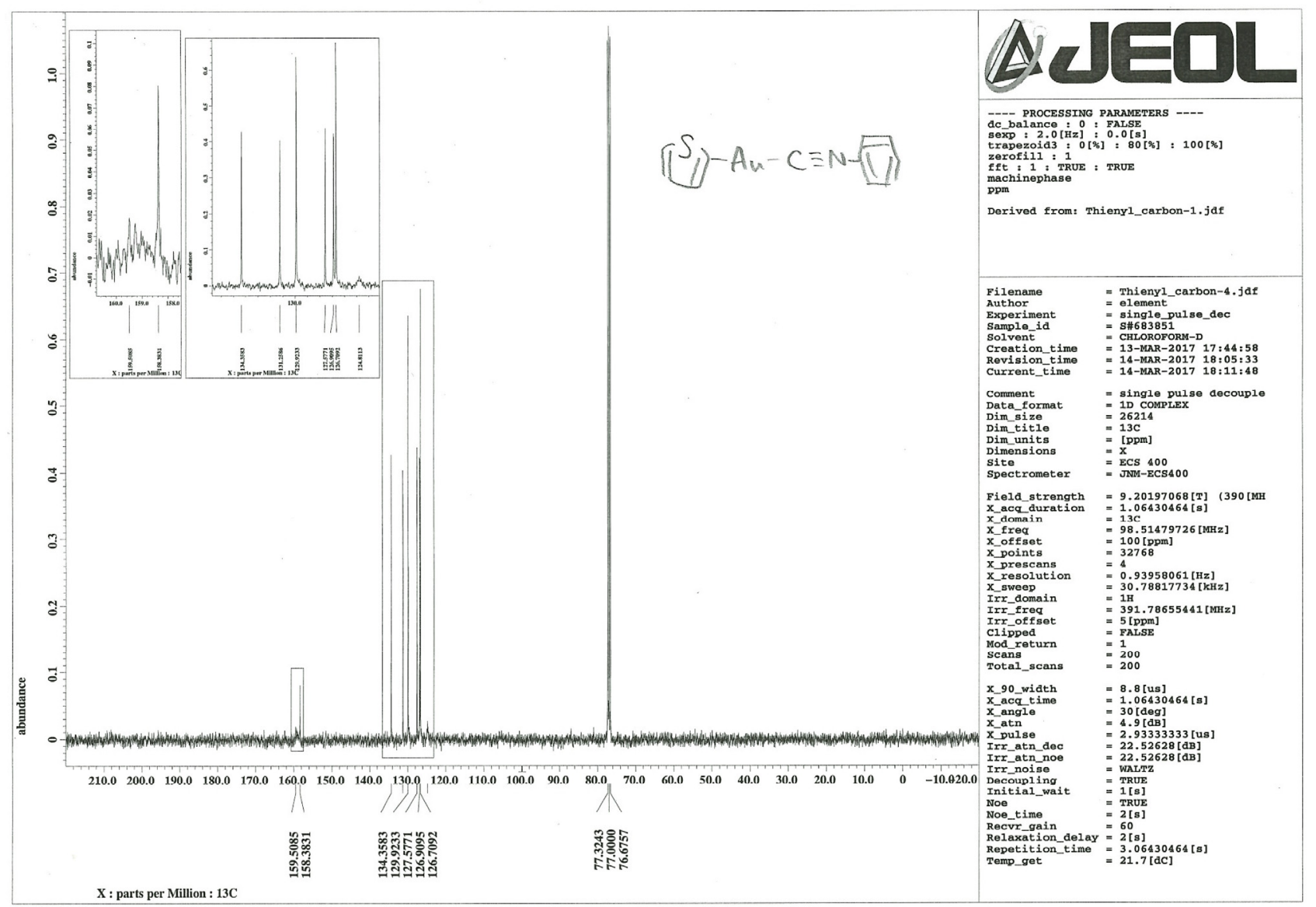

Fig. S20 ${ }^{13} \mathrm{C}$ NMR spectrum of $\mathbf{1}$ dissolved in $\mathrm{CDCl}_{3}$.

\section{References}

1. Sheldrick, G. M. Acta Crystallogr. Sect. A 2015, 71, 3.

2. http://www.ccdc.cam.ac.uk/free_services/mercury/downloads/Mercury_3.0/ 